\title{
The Hsa_circ_009/579/miR-940/TACRI Axis Regulates the Development of Hepatocellular Carcinoma [Retraction]
}

Jiang P, Han W, Fu Y, Chen Q. Cancer Manag Res. 2020;12:9087-9096.

At the authors request, the Editor and Publisher of Cancer Management and Research wish to retract the published article. Since completing the study the authors have been unable to reproduce the results reported and have determined the findings are invalid.
Our decision-making was informed by our policy on publishing ethics and integrity and the COPE guidelines on retraction.

The retracted article will remain online to maintain the scholarly record, but it will be digitally watermarked on each page as "Retracted".

\section{Publish your work in this journal}

Cancer Management and Research is an international, peer-reviewed open access journal focusing on cancer research and the optimal use of preventative and integrated treatment interventions to achieve improved outcomes, enhanced survival and quality of life for the cancer patient.
The manuscript management system is completely online and includes a very quick and fair peer-review system, which is all easy to use. Visit http://www.dovepress.com/testimonials.php to read real quotes from published authors. 